\title{
Studi Perencanaan Moda Transportasi Penumpang Antar Terminal Bandara Juanda Surabaya
}

\author{
Indra Denny Priatna, Ervina Ahyudanari, Istiar \\ Departemen Teknik Sipil, Fakultas Teknik Sipil dan Perencanaan, Institut Teknologi Sepuluh Nopember (ITS) \\ e-mail: ervina@ce.its.ac.id
}

\begin{abstract}
Abstrak-Bandara Juanda memiliki kapasitas 12,5 juta penumpang pertahun namun harus melayani hingga 17 juta penumpang. Pertumbuhan penumpang sebesar $16, \%$ per tahunnya (Angkasa Pura I,2015) sehingga Bandara Juanda sudah mengalami Overcapacity.Untuk mengatasi hal tersebut,pihak Angkasa Pura I merencanakan pengembangan Bandara Juanda dengan menambah dua landasan pacu dan satu gedung terminal penumpang. diharapkan kedepanya bandara Juanda dapat melayani 75 juta penumpang per tahunnya. Lokasi dari ketiga terminal tersebut terpisah kan oleh landasan pacu dan tidak memungkinkan adanya penghubung dalam jarak dekat.melihat kondisi terminal penumpang dari Bandara Juanda dan estimasi peningkatan penumpang dalam beberapa tahun kedepan, ada beberapa permasalahan yang perlu di tinjau guna meningkatkan pelayanan pada Bandara Juanda. Permasalahan yang dimaksud adalah bentuk pelayanan pada penumpang transit yang berpindah terminal. Oleh karena itu pada penulisan studi ini dilakukan studi perencanaan transportasi penumpang antar terminal Bandara Juanda guna mengantisipasi demand transportasi antar terminal yang diakibatkan peningkatan jumlah penumpang,disamping itu memahami kondisi pergerakan penumpang pada bandara dan melakukan perencanaan moda transportasi sebagai upaya pengembangan bandara guna meningkatkan kualitas dari perjalanan pada Bandara Juanda Surabaya. Hasil yang didapatkan dari perencanaan ini adalah rekomendasi moda transportasi penumpang antar terminal yang efisien menghubungkan ketiga terminal bandara Juanda Surabaya.
\end{abstract}

Kata kunci-Transportasi Antar Terminal, Bandara, Juanda.

\section{PENDAHULUAN}

$\mathrm{B}$ ANDAR udara Juanda adalah bandara udara terbesar di Jawa Timur dan merupakan bandara utama bagi Kota Surabaya dan sebagian besar wilayah di Jawa Timur. Seiring dengan semakin pesatnya berkembangnya wilayah Jawa Timur,bandara udara Juanda mengalami peningkatan jumlah penumpang yang cukup tinggi dari tahun ke tahun. Jumlah penumpang bandara Juanda sudah mencapai 17,662,593 penumpang pada tahun 2013 dan mengalami peningkatan penumpang hampir sebesar 15\% selama tahun 2009-2013 [1]. Kondisi ini menyebabkan bandara Juanda mengalami over capacity dimana terminal 1 dan terminal 2 hanya memiliki kapasitas sekitar 12,5 juta penumpang pertahun.

Sebagai bandara udara utama wilayah Jawa Timur yang merupakan pintu gerbang ekonomi Indonesia bagian Timur,bandara Juanda diharapkan dapat melayani penerbangan sebagian besar perjalanan menuju Indonesia Timur dengan jumlah penduduk sekitar 91,13 juta jiwa (Jawa Timur, Kalimantan, Sulawesi, Maluku, Papua, Bali, NTB \& NTT) [2] dan sebagian proporsi penerbangan internasional dari bandara Soekarno-Hatta.Namun hal ini belum bisa dicapai dikarenakan rute dan jadwal penerbangan bandara Juanda yang terbatas dikarenakan pesawat dari terminal 1 dan 2 masih harus berbagi runway dikarenakan bandara Juanda hanya memiliki satu landasan pacu saja.Untuk mengantisipasi peningkatan penumpang bandara beberapa tahun kedepan, PT.Angkasa Pura I Merencanakan pengembangan bandara Juanda dengan menambah 2 lajur runway dan terminal 3 yang di rencanakan dapat melayani 75 juta penumpang pertahunnya.

PT. Angkasa Pura I merencanakan bandara Juanda sebagai Airport City dengan 3 runway dan 3 terminal pada lahan seluan 4.000 Ha. Lokasi rencana dari terminal 3 ultimate itu sendiri berada di sebelah timur laut dari terminal 1 [3]. Lokasi dari ketiga terminal ini terletak berjauhan menyebabkan sulitnya akses untuk berpindah terminal. Pada kondisi existing terminal 1 dan 2 dipisahkan oleh adanya runway diantara kedua terminal tersebut. Terbatasnya akses bandara terminal 2 karena terletak pada daerah TNI Angkatan Laut membuat terminal bandara Juanda tidak bisa terintegrasi secara total. Moda transportasi penumpang antar terminal pun hanya terbatas menggunakan mobil pribadi, shuttle bus dan taxi.

Oleh karena itu diperlukan studi perencanaan transportasi penumpang antar terminal untuk memahami kondisi pergerakan penumpang pada bandara dan melakukan perencanaan moda transportasi sebagai upaya pengembangan bandara guna meningkatkan kualitas dari perjalanan pada bandara Juanda Surabaya. Hasil yang diharapkan dari perencanaan ini adalah adanya system transportasi penumpang antar terminal yang sesuai dengan layout bandara Juanda dengan ketiga terminalnya.

\section{METODOLOGI}

Metode yang digunakan dalam studi perencanaan ialah sebagai berikut

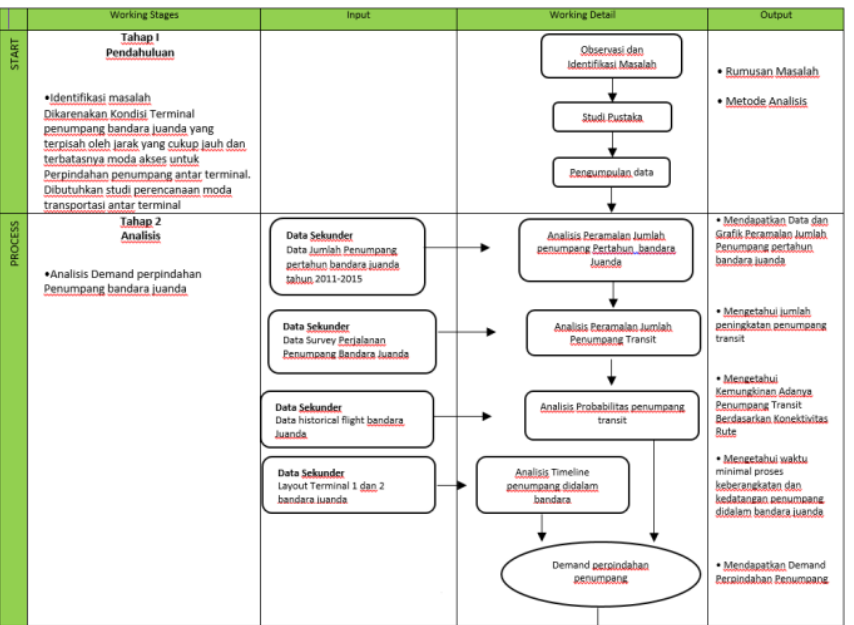




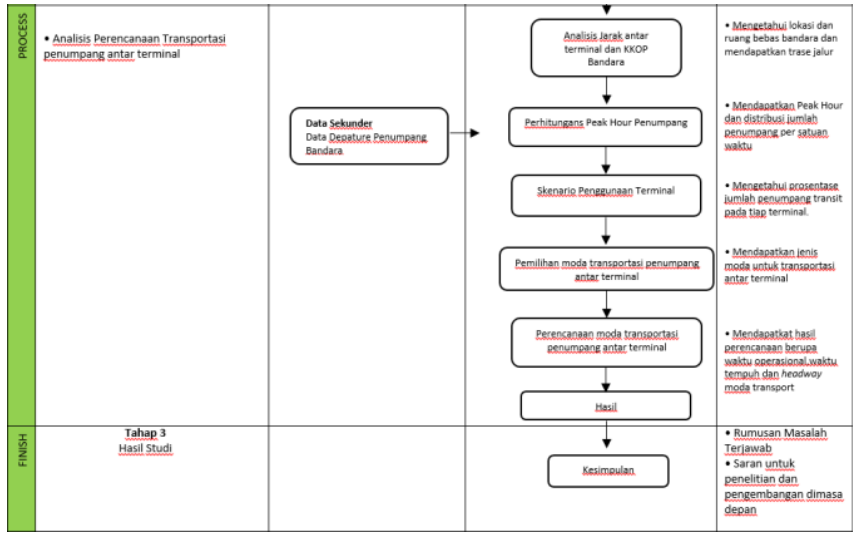

Gambar 1. Diagram Alir Metodologi Studi Perencanaan

\section{ANALISIS DAN PEMBAHASAN}

\section{A. Analisis Peramalan Jumlah Penumpang Transit}

Peramalan jumlah penumpang dilakukan dengan menggunakan metode regresi linier. Rata-rata pada tahuntahun kedepan dengan menggunakan data mengenai pergerakan penumpang dan jumlah penumpang pada tahuntahun sebelumnya.

Tabel 1.

Data Penumpang Bandara Juanda pertahun [4]

\begin{tabular}{|c|c|c|c|c|c|c|}
\hline \multirow[b]{2}{*}{ Tahun } & \multicolumn{3}{|c|}{ Airport JUANDA } & \multirow[b]{2}{*}{ Transit } & \multirow[b]{2}{*}{ Lokal } & \\
\hline & & Datang & Berangkat & & & \multirow{4}{*}{13778287} \\
\hline \multirow[t]{5}{*}{2011} & Pesawat & 55.326 & 55.333 & & 0 & \\
\hline & Penumpang & 6.693 .222 & 6.299 .016 & 786.049 & & \\
\hline & Bagasi & 48.394 .940 & 57.168 .618 & & & \\
\hline & Kargo & 47.326 .702 & 47.818 .841 & & & \multirow{7}{*}{16447912} \\
\hline & Pos & 933.649 & 934.496 & & & \\
\hline \multirow[t]{5}{*}{2012} & Pesawat & 65.686 & 65.763 & & 4.721 & \\
\hline & Penumpang & 8.150 .014 & 7.479 .228 & 818.67 & & \\
\hline & Bagasi & 60.451 .603 & 64.556 .240 & & & \\
\hline & Kargo & 44.582 .303 & 61.432 .644 & & & \\
\hline & Pos & 428.243 & 1.087 .365 & & & \\
\hline \multirow[t]{5}{*}{2013} & Pesawat & 67.384 & 67.349 & & 0 & \multirow{3}{*}{17683854} \\
\hline & Penumpang & 8.827 .267 & 8.036 .800 & 819.787 & & \\
\hline & Bagasi & 66.296 .498 & 67.331 .947 & & & \\
\hline & Kargo & 36.759 .651 & 58.842 .697 & & & \multirow{7}{*}{17337726} \\
\hline & Pos & 84.337 & 860.824 & & & \\
\hline \multirow[t]{5}{*}{2014} & Pesawat & 65.593 & 65.595 & & 0 & \\
\hline & Penumpang & 8.651 .672 & 8.074 .575 & 611.479 & & \\
\hline & Bagasi & 64.415 .120 & 60.760 .188 & & & \\
\hline & Kargo & 41.736 .531 & 56.547 .756 & & & \\
\hline & Pos & 35.678 & 508.646 & & & \\
\hline
\end{tabular}

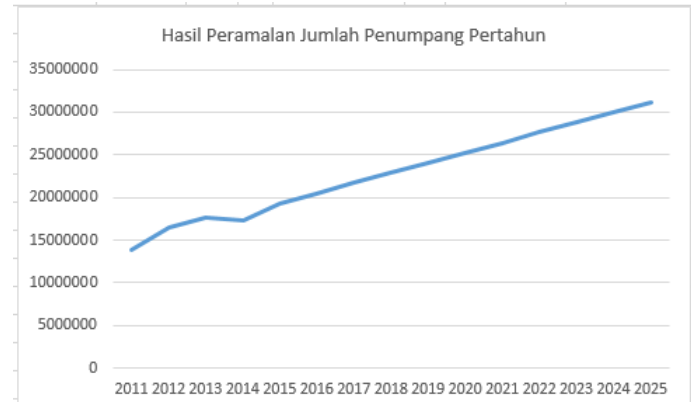

Gambar 2. Grafik Hasil Peramalan Jumlah Penumpang Pertahun

Untuk analisis peramalan jumlah penumpang transit dilakukan dengan melihat perbandingan jumlah prosentase penumpang transit terhadap jumlah penumpang total pertahun.Untuk mendukung analisis penulis tentang prosentase penumpang transit, penulis menganalisis hasil survey penumpang pada bandara Juanda yang dilakukan oleh Litbang Perhubungan Antar Moda, Kementrian Perhubungan, 2016. dimana didalam survey tersebut terdapat
720 koresponden lengkap dengan data asal dan tujuan penumpang.

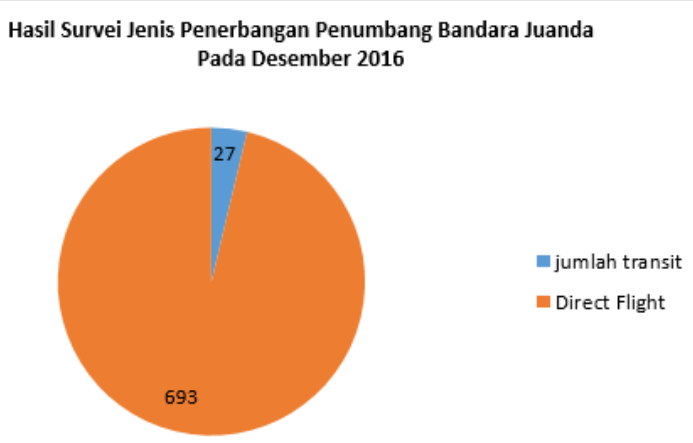

Gambar 3. Hasil Survei Jenis Penerbangan Penumpang

Hasil dari analisis survey penumpang secara langsung menunjukan sekitar $3,75 \%$ dari total sample sedang transit dan $3,52 \%$ merupakan prosentase yang paling mendekati hasil suvey. Sehingga prosentase $3.75 \%$ ini akan digunakan dalam peramalan jumlah penumpang transit pada tahun-tahun kedepan.

\section{B. Analisis Probabilitas Penumpang Transit}

Untuk mengetahui distribusi asal tujuan penumpang pada tahapan ini dilakukan analisis terhadap rute penerbangan yang tersedia dari bandara Juanda tujuannya adalah untuk melihat hubungan bandara terhadap bandara lainnya dan probabilitas bandara Juanda sebagai tempat untuk transit.Dari data historis keberangkatan/kedatangan bandara Juanda [5] didapatkan 39 rute penerbangan.

Untuk mengetahui probabilitas penumpang transit pada bandara Juanda dilakukan simulasi rute penerbangan pada masing kota yang terdapat pada rute penerbangan yang tersedia di bandara Juanda. Klarifikasi penerbangan menggunakan situs flightconnections.com karena menyediakan informasi jadwal penerbangan,maskapai,waktu tempuh dan lokasi-lokasi transit.Sehingga dapat diketahui kemungkinan bandara Juanda sebagai tempat transit.

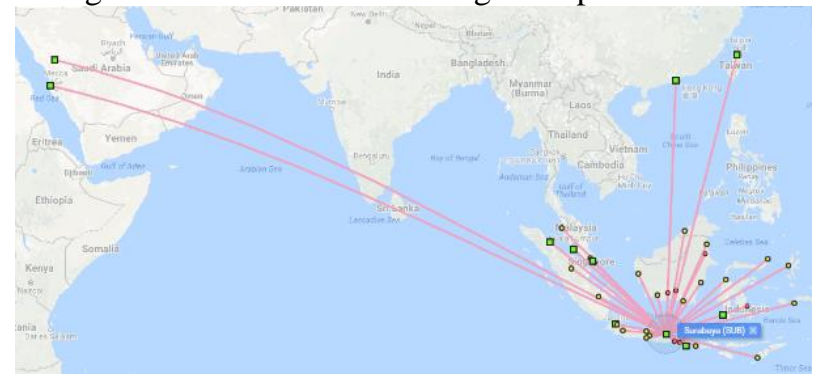

Gambar 4. Rute Penerbangan Bandara Juanda [6]

Dari semua simulasi tersebut didapatkan total 1482 rute penerbangan pada 39 kota sebesar 899 penerbangan $(60,66 \%)$ berkemungkinan membawa penumpang yang akan transit pada bandara Juanda dan 583 penerbangan (39.33\%) tidak.

\section{Analisis Timeline Penumpang Didalam Bandara}

Dalam analisis ini dilakukan perkiraan waktu tempuh penumpang pada saat proses keberangkatan dan kedatangan. Analisis ini dilakukan guna mengetahui berapa lama waktu yang dibutuhkan penumpang apabila terdapat situasi yang mengharuskan penumpang untuk berpindah terminal saat melakukan connecting flight. Hal ini dikarenakan terminal 1 dan terminal 2 tidak terhubung secara internal dan 
penumpang harus melakukan prosedur keberangkatan lagi saat tiba di terminal lainnya.

Analisis yang dilakukan adalah berupa simulasi waktu perjalanan penumpang saat melakukan proses keberangkatan dan kedatangan tujuannya adalah agar dapat mengetahui waktu minimal yang dibutuhkan penumpang untuk transit sebagai pertimbangan dalam merencanakan moda transportasi antar bandara.

Dari timeline dari masing-masing skenario didapatkan waktu tempuh penumpang saat prosedur keberangkatan dan kedatangan

Tabel 2.

Waktu Tempuh Pergerakan Penumpang Didalam Bandara

\begin{tabular}{|l|l|l|}
\hline Proses & $\begin{array}{l}\text { Waktu tempuh } \\
\text { (Detik) }\end{array}$ & $\begin{array}{l}\text { Pembulatan } \\
\text { (Menit) }\end{array}$ \\
\hline $\begin{array}{l}\text { Keberangkatan } \\
\text { Domestik Terminal 1 }\end{array}$ & 1281.06 & 22 \\
\hline $\begin{array}{l}\text { Kedatangan Domestik } \\
\text { Terminal 1 }\end{array}$ & 407.24 & 7 \\
\hline $\begin{array}{l}\text { Keberangkatan } \\
\text { Domestik Terminal 2 }\end{array}$ & 1468.94 & 25 \\
\hline $\begin{array}{l}\text { Kedatangan Domestik } \\
\text { Terminal 2 }\end{array}$ & 204.96 & 4 \\
\hline $\begin{array}{l}\text { Keberangkatan } \\
\text { Internasional Terminal 2 }\end{array}$ & 2072.68 & 15 \\
\hline $\begin{array}{l}\text { Kedatangan } \\
\text { Internasional Terminal 2 }\end{array}$ & 904.12 & 35 \\
\hline
\end{tabular}

Setelah didapat perkiraan waktu dari masing-masing proses, scenario waktu minimal yang diperlukan penumpang untuk transit adalah sebagai berikut

-Domestik T1 $\rightarrow$ Domestik T2

= Kedatangan Domestik T1 + Keberangkatan Domestik T2

$=7$ menit +25 menit

$= \pm 32$ menit

-Domestik T2 $\rightarrow$ Domestik T1

$=$ Kedatangan Domestik T2 + Keberangkatan Domestik T1

$=4$ menit +22 menit

$= \pm 26$ menit

-Domestik T1 $\rightarrow$ Internasional T2

= Kedatangan Domestik T1 + Keberangkatan Internasional $\mathrm{T} 2$

$=7$ menit +35 menit

$= \pm 42$ menit

-Internasional T2 $\rightarrow$ Domestik T1

$=$ Kedatangan Internasional T2 + Keberangkatan Domestik $\mathrm{T} 1$

$=15$ menit +22 menit

$= \pm 37$ menit

\section{Demand Perpindahan Penumpang}

Pada analisis-analisis sebelumnya didapatkan didapatkan hasil sebagai berikut :

-Jumlah peningkatan penumpang transit pertahun pada tahun 2025 mencapai 1.170 .179 jiwa dengan rata-rata 3288 penumpang perhari

-Probabilitas adanya penumpang transit berdasarkan rute penerbangan pada bandara Juanda didapatkan dari 1482 rute penerbangan terdapat 899 rute penerbangan yang berpotensi membawa penumpang transit atau sekitar $60,66 \%$ dari total penerbangan.

-Waktu proses saat connecting flight didalam bandara itu sendiri memakan waktu paling cepat sekitar 26 menit pada transit Domestik T2 $\rightarrow$ Domestik T1 dan paling lama sekitar 42 menit pada transit Domestik T1 $\rightarrow$ Internasional T2. Dan waktu ini belum termasuk perjalanan berpindah terminal.

Dari ketiga poin diatas maka diperlukan adanya moda transportasi antar terminal bandara Juanda yang efektif untuk menunjang kebutuhan penumpang bandara Juanda.

\section{E. Perhitungan Jarak dan KKOP Bandara}

Pada tahapan ini dilakukan analisis jarak antara terminal 3 Juanda dengan terminal 1 dan 2 . lokasi teminal 3 bandara Juanda berada pada sekitar koordinat Latitude -7.367009 Longitude 112.826087 [7] [8]

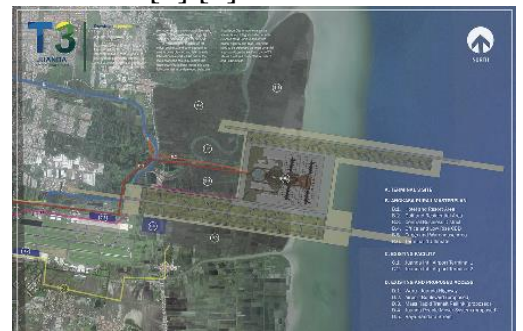

Gambar 5. Lokasi Terminal 3 Bandara Juanda [7]

Apabila koordinat latitude -7.367009 dan longitude 112.826087 ditetapkan sebagai titik point lokasi terminal 3 Juanda jarak antara terminal dapat diukur

Kemudian panjang trase diukur dengan menggunakan Google Earth dan didapatkan :

Terminal $1-$ Terminal $3=3.60 \mathrm{~km}$.

Terminal $1-$ Terminal $2=4.78 \mathrm{~km}$
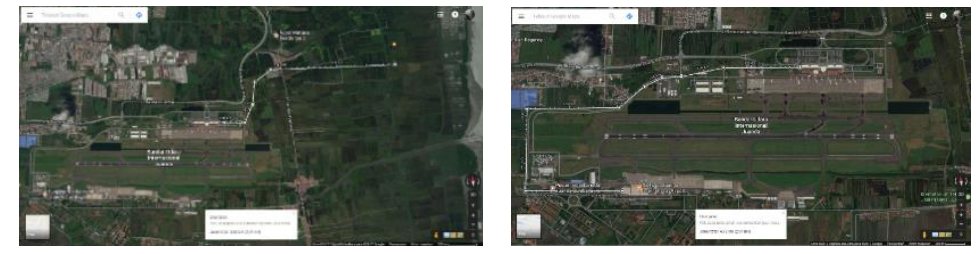

Gambar 6. Jarak Trase Moda transportasi [8]

Salah satu kondisi yang menjadi permasalahan bandara Juanda adalah akses ketiga terminal yang dipisahkan dengan landasan pacu. Oleh karena itu perlu dilakukan analisis KKOP terhadap Aproach Surface landasan pacu agar tidak menggangu sistem navigasi, direncanakan jalur akses yang memiliki jarak kira-kira 60 meter disamping sumbu landasan,75 meter dari threshold arah pendaratan.

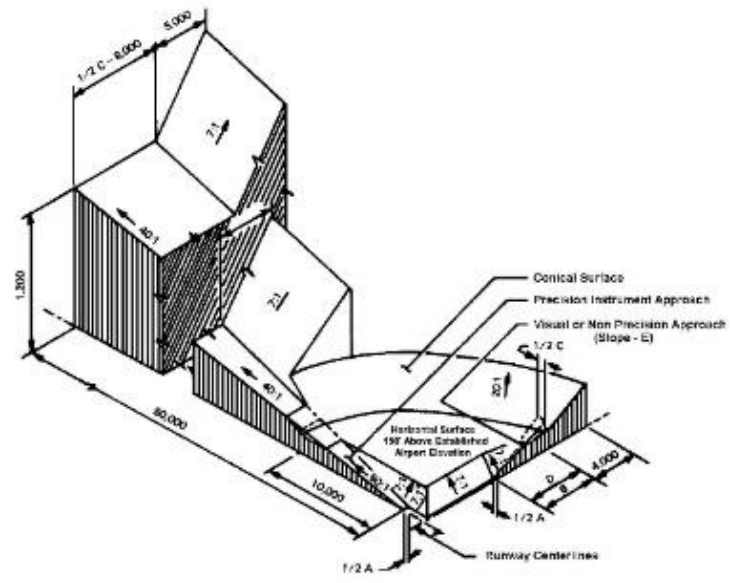

Gambar 7. Imaginary Surface [9]

Perhitungan penentuan halangan untuk navigasi 
1. Menentukan titik yang ditinjau terhadap awal approach surface yaitu $707.14 \mathrm{~m}-60.96 \mathrm{~m}=$ $646.18 \mathrm{~m}$

2. Dari titik yang ditinjau, tinggi approach surface adalah $(1: 50) \rightarrow 646.18: 50=12.9236 \mathrm{~m}$

3. Titik tertinggi moda adalah diperkirakan $<6 \mathrm{~m}$

4. Karena titik tertinggi Moda lebih kecil dari batasan tinggi approach surface ( $6 \mathrm{~m}<12.9 \mathrm{~m}$ ) maka Moda tidak menjadi halangan bagi navigasi.

\section{F. Perhitungan Distribusi Penumpang Berdasarkan Peak Hour}

Perhitungan Peak Hour penumpang dilakukan untuk mengetahui distribusi jumlah penumpang per satuan waktu tertentu.perhitungan dilakukan dengan menghitung kedatangan penumpang per jam dengan pola distribusi kedatangan penumpang berdasarkan IATA [10]. Setelah pengolahan data selesai, digunakan data jumlah penumpang peak-hour tertinggi.

Setelah diketahui distribusi penumpang berdasarkan peak hour. Akan didapat jumlah penumpang per 10 menit. Nantinya data ini akan digunakan sebagai penentuan jumlah kapasitas moda transportasi dan waktu oprasional.

Perhitungan jumlah penumpang peak-hour dilakukan menggunakan pola distribusi kedatangan penumpang per 10 menit berdasarkan IATA. Berdasarkan data yang diperoleh selama 7 hari, didapatkan jumlah penumpang peak-hour sebagai berikut

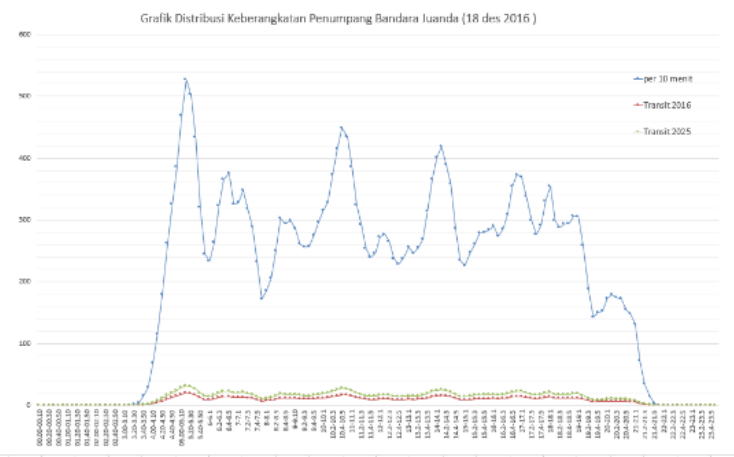

Gambar 8. Grafik Distribusi Penumpang Peak Hour

Dari grafik tersebut diatas, jumlah penumpang terbanyak adalah pada tanggal 18 Desember 2016 sejumlah 29630 penumpang.distribusi penumpang transit puncak terdapat pada pukul 05.20-05.30 dengan jumlah sekitar 31 orang.

\section{G. Skenario Penggunaan Terminal}

Scenario penggunaan Terminal dilakukan untuk mengetahui perkiraan jumlah prosentase penumpang yang akan berpindah Terminal berdasarkan sifat dari Terminal penumpang bandara dan maskapai penerbangan yang direncanakan. Direncanakan skenario penggunaan Terminal sebagai berikut :

\section{T1 : Terminal Domestik LCC (low Cost Carrier) \\ T2 : Terminal Khusus haji-umroh \\ T3 : Terminal Internasional}

Dilakukan klarifikasi rute penerbangan berdasarkan masing-masing maskapai dari situs flightconnection.com. untuk mengetahui rute penerbangan yang dilayani oleh masing-masing maskapai pada setiap terminal.
Setelah didapat rute penerbangan masing-masing maskapai per terminal,dilakukan analisis dengan tabel matriks probabilitas penumpang transit untuk mendapatkan Prosentase transit per terminal.hasil prosentase dapat dilihat pada tabel dibawah ini

Tabel 3.

Prosentase Perpindahan Per Terminal

\begin{tabular}{|c|c|c|c|}
\hline \multicolumn{4}{|c|}{ Prosentase Perpindahan Per Terminal } \\
\hline Teri & Terminal 1 & Terminal 2 & Terminal 3 \\
\hline Terminal 1 & & $5.67 \%$ & $48.16 \%$ \\
\hline Terminal 2 & $5.78 \%$ & & $1.11 \%$ \\
\hline
\end{tabular}

H. Pemilihan Moda Transportasi Penumpang Antar terminal

Sebagai pertimbangan dalam memilih moda transport dari perhitungan sebelumnya didapatkan data-data sebagai berikut:

-Jarak Trase

Terminal $1-$ Terminal $3=3.60 \mathrm{~km}$.

Terminal $1-$ Terminal $2=4.78 \mathrm{~km}$

- Jumlah Penumpang

Tertinggi per 10 menit $=31$

-Waktu penumpang aktif $=03.20-21.40$

Dari pengamatan-pengamatan sebelumnya karakteristik perpindahan penumpang pada bandara Juanda memiliki jumlah yang tidak terlalu besar akan tetapi karena faktor jarak yang cukup jauh dibutuhkan moda transportasi yang cepat. Moda transportasi yang dirasa sesuai dengan kebutuhan tersebut adalah Automated People Mover.

Berdasarkan hasil analisis Sabila Desvi (2015) tentang pemilihan moda transportasi antar terminal bandara, Moda transportasi yang dinilai sesuai dengan kebutuhan tersebut adalah Automated People Mover [11].

Automated People Mover merupakan moda transportasi yang paling sering dipilih sebagai fasilitas transportasi penumpang pada bandara-bandara diluar negeri karenakan cepat dan dapat di operasikan secara otomatis sehingga menjamin ketepatan waktu .

Untuk moda transportasi penumpang bandara Juanda direncanakan menggunakan Mitsubishi Heavy Industries Crystal mover C810A [12] dengan spesifikasi sebagai berikut:

- Manufacturer : Mitsubishi Heavy Industries

- Type : Crystal Mover C810A

- Configuration: Single-car or Double-car

- Capacity (passengers): 105 (including 18 seats) or 210 (including 36 seats)

- Vehicle mass (t): 14.9/vehicle

- Vehicle dimensions (mm): 12550 (length) $\times 2690$ (width) $\times 3725$ (height)

- Guide system: Side guide two-axis four-wheel steering system

- Electric system: 750 Volts Direct Current

- Gauge (mm): Gauge, 1 850; guide rail span, 3200

- Maximum speed

- Vehicle performance: $80 \mathrm{~km} / \mathrm{h}$ 
- Operation: $70 \mathrm{~km} / \mathrm{h}$

- Acceleration: $1.0 \mathrm{~m} / \mathrm{s}^{2}(3.6 \mathrm{~km} / \mathrm{h} / \mathrm{s})$

- Deceleration

- Maximum service: $1.0 \mathrm{~m} / \mathrm{s}^{2}(3.6 \mathrm{~km} / \mathrm{h} / \mathrm{s})$

- Emergency: $1.3 \mathrm{~m} / \mathrm{s}^{2}(4.7 \mathrm{~km} / \mathrm{h} / \mathrm{s})$

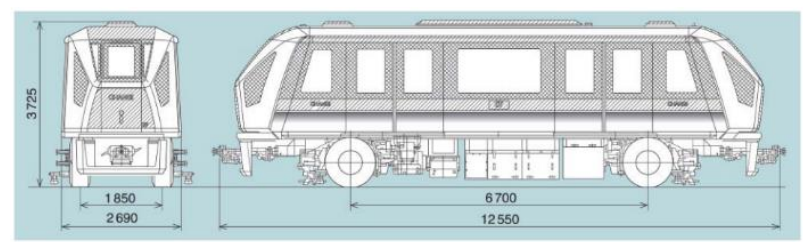

Gambar 9. Dimensi Automated People Mover [12]

\section{Perencanaan Moda Transportasi Penumpang Antar terminal}

Waktu oprasional moda transport direncanakan melalui hasil grafik distribusi penumpang peak hour. Berdasarkan grafik penumpang peak hour pada tanggal 18 Desember 2016 diperkirakan penumpang pertama datang pada jam 3.20 dan penumpang terakhir pada jam 21.40 sehingga direncanakan waktu operasional APM adalah pada pukul 03.00-22.00.

Selanjutnya adalah dilakukan perencanaan Headway moda transport untuk mengetahui waktu tempuh dan frekuensi oprasional APM. Pada analisis sebelumnya diketahui bahwa karena keterbatasan lokasi Jalur trase moda tidak bisa terintegrasi secara total sehingga direncanakan moda transport APM hanya menghubungkan Termianl 1 dengan Terminal 2 dan Terminal 1 dengan Terminal 3. Didapatkan jarak trase antar Terminal 1 dengan Terminal 3 adalah $3.6 \mathrm{~km}$ dan jarak Terminal 1 dengan Terminal 2 adalah $4.78 \mathrm{~km}$ serta kecepatan operasional yang dapat dicapai moda APM adalah $70 \mathrm{~km} / \mathrm{jam}$

Waktu sekali tempuh moda APM dapat dihitung dengan persamaan dibawah ini

$\frac{\operatorname{Jarak}(\mathrm{Km})}{\operatorname{Kecepatan}(\mathrm{Km} / \mathrm{jam})} \times 60$

Sehingga didapatkan:

-Waktu tempuh T1-T3

$\frac{3.6 \mathrm{Km}}{70 \mathrm{Km} / \mathrm{jam}} \times 60=3$ menit

-Waktu tempuh T1-T2

$\frac{4.78 \mathrm{Km}}{70 \mathrm{Km} / \mathrm{jam}} \times 60=4$ menit

Direncanakan terdapat 2 unit APM dengan rel berbeda pada setiap jalur untuk meningkatkan frekuensi oprasional APM sehingga unit APM dapat mengantar penumpang pada tiap terminal setiap 5 menit.

1) Crystal Mover C810A memiliki dimensi tinggi $3725 \mathrm{~mm}$ yang lebih kecil dari batasan tinggi approach surface (12900 mm) sehingga tidak mengganggu navigasi.

2) Kapasitas satu rangkaian $\mathrm{C} 810 \mathrm{~A}$ dapat menampung 105 orang dan 19 tempat duduk dan bisa disambung menjadi dua rangkaian untuk meningkatkan kapasitas.

3) Kecepatan oprasional C810A adalah $70 \mathrm{~km} / \mathrm{jam}$ sehingga jarak Terminal 1-Terminal 3 dapat ditempuh dalam waktu 4 menit dan Terminal 1-Terminal 2 dalam waktu 5 menit
4) Karena keterbatasan lahan, APM tidak memiliki akses langsung Terminal 2-Terminal 3 sehingga harus melalui Terminal 1.

5) Headway APM pada tiap Terminal adalah 5 menit.

\section{KESIMPULAN}

Berdasarkan hasil analisis yang telah dilakukan, dapat diperoleh beberapa kesimpulan, antara lain:

1) Berdasarkan peramalan jumlah penumpang,pada tahun 2025 jumlah penumpang transit dapat mencapai 3278 penumpang/hari dan didapatkan bahwa prosentase jumlah penumpang transit sebesar $3.75 \%$ dari jumlah penumpang pertahun.

2) Perkiraan waktu minimal yang ditempuh oleh penumpang saat melakukan connecting flight adalah 26 menit pada penerbangan domestik terminal 2 menuju terminal 1

3) Dari analisis jarak dan Pemilihan moda transportasi bandara,dibutuhkan moda transportasi yang cepat dan memiliki tingkat frekuensi perjalanan yang tinggi. Automated People Mover merupakan moda transportasi yang ideal karena dengan kecepatan oprasional yang cukup tinggi dan efisien kaena dapat dijalankan secara otomatis.

\section{A. Saran}

1) Studi Perencanaan Moda Transportasi ini diharapkan dapat menghasilkan rekomendasi-rekomendasi perencanaan terkait dengan moda transportasi pada bandara Juanda.

2) Dibutuhkan penelitian lebih lanjut terkait dengan terminal 3 bandara Juanda dikarenakan belum adanya informasi mengenai rencana pengembangan bandara kedepannya.

\section{DAFTAR PUSTAKA}

[1] A. Yustinian, “<https://juanda-airport.com/en/news/index/>," Airport Juanda News, 2014.

[2] B. P. S. I. (2005-2014), Indonesia Dalam Angka. Surabaya.

[3] Boulevard, "http://www.juandaairport.com/2016/07/proyekterminal-3-bandara-juanda.html," Info Penerbangan dan Akomodasi Surabaya, 2016. [Online]. Available: http://www.juandaairport.com/2016/07/proyek-terminal-3bandara-juanda.html.

[4] Direktorat Jenderal Perhubungan Udara, "Direktorat Jenderal Perhubungan Udara." [Online]. Available: http://hubud.dephub.go.id/?id/bandara/index/page:30.

[5] Flightconnections, "http://www.flightconnections.com," (SUB) Juanda Airport Route, 2016. [Online]. Available: http://www.flightconnections.com.

[6] Flightware, "http://www.flightaware.com," SUB) Juanda International Airport Depature, 2016. [Online]. Available: http://www.flightaware.com.

[7] H. Ginting, “<https://www.behance.net/gallery/27948857/," Juanda International Airport: Terminal 3, 2015. .

[8] G. Earth, "Earth, Google," Earth, Google, 2017. .

[9] Keputusan Direktur Jendral Perhubungan Udara Nomor SKEP /110/VI/2000 tentang Petunjuk Pelaksanaan Pembuatan Kawasan Keselamatan Operasi Penerbangan Di Bandar Udara Dan Sekitarnya. 2000.

[10] IATA, Airport Development Reference Manual, 9th Edition.

[11] S. Desvi, "Studi Pemilihan Moda Akses Antar Terminal Bandara 
Juanda," 2015 .

[12] A. Kashiwa, M., Hiiroyuki, M., Yamamoto, "Mitsubishi Heavy Industries, LTD. Technical Review," vol. 44, no. 2, 2007. 